\title{
A Study of Technology Diffusion and Productivity Levels in the Natural Rubber Industries of Cambodia and Thailand by Adopting the Analytic Hierarchy Process
}

\author{
Nobuo Hirohata \\ Graduate School of Innovation and Technology Management, Yamaguchi University, Yamaguchi, Japan \\ (E-mail: hirohata@yamaguchi-u.ac.jp)
}

\begin{abstract}
The paper focuses on the productivity of the natural rubber industries of Cambodia and Thailand by analyzing the diffusion of agricultural and industrial technologies throughout the planting, cultivating and primary processing by adopting the analytic hierarchy process. The paper draws a conclusion that the technology diffusion in Cambodia is behind especially in terms of clone technologies in the agriculture process, foreign materials removal technologies in the industrial process, and the gap of human resources and research institute related to natural rubber industries are highlighted.
\end{abstract}

Key words: Technology diffusion; Natural rubber; Cambodia; AHP

\section{Introduction}

The production quantity of primary processed natural rubbers in 2007 was 9.89 million tons and the quantity has annually increased by the average of $5.6 \%$ since 2000 (International Rubber Study Group, 2008). Under the background of globally natural resource shortage, natural rubbers has been catching more attraction as raw materials for automobiles tires and reclaimable agricultural resources. Effort has been made to increase production in Southeast Asian developing countries. Nevertheless its productivity has remained at low level and diffusion of necessary technologies has been slow. The natural rubber industry is characterized as a manufacturing segment to produce raw materials based on agricultural resource for the industry.

To promote productivity of the natural rubber industry, it is necessary to diffuse agricultural technologies of natural rubber's planting and cultivation and industrial technologies to process sap of natural rubber to primary products. In addition, it needs to diffuse technologies of transportation, storage, management of manufacturing process and laboratory function and quality control ability of the staff. According to the data of International Rubber Study Group (2008), most of countries improved the productivity in spite of some differences in the rate, only Cambodia has shown no productivity increase from 2000 through 2005. This study analyzes from the view point of innovation diffusion of the Cambodian natural rubber industry that is expected to have various problems to block improvement of productivity. In this analysis comparison with the situation of Thailand that produces natural rubber in the most quantity with the highest productivity and has similar cultures and regime as a neighboring country was made. Then by using Analytic Hierarchy Process developed by Satty (1980), various blocking factors associated with productivity improvement in Cambodia was clearly analyzed, such as factors about agricultural technologies, industrial technologies and overall manufacturing process from the viewpoint of innovation diffusion.

\section{Study of Concept in Relation to Technology Diffusion}

Rogers (2003) explained that innovation takes six development processes; (1) comprehension of problems and needs, (2) research of fundamentals and applications, (3) development of technology, (4) commercialization of research accomplishment, (5) diffusion and introduction of technology, (6) conclusion of innovation. In this theory, diffusion of technology is defined as the process in which innovation is conveyed to the components of social system through communication channels during the elapse of time. Watanabe (1978) 
divided agricultural technologies into technology about tangible and physical production method and technology about intangible and intellectual production method. For the former he divided them into manufacturing method such as instruments and machineries and processing objects such as raw materials and for the latter he divided them into intellectual technology and skill technology. With regard to industrial technologies, Komoda (1987) mentioned that it is necessary to transfer technologies from other sources in addition to own research and development in order to improve productivity. The modes of transfer are divided into the modes, in which technologies come through the markets and the non-market modes. Watanabe, Miyazaki and Katsumoto (1998) divided transfer of industrial technology into built-in type and non-built-in type. Built-in type technologies are diffused into the recipients by purchasing intermediate goods or capital goods in which technologies are built-in and they are evaluated in the market in terms of price and benefit to users. Non-built-in type technologies are not brought by convey of describable technical knowledge and purchase of products in which new technologies are built-in. New technologies and knowledge to be transferred are considered to have public assets.

\section{Research Method}

In this study the analytic hierarchy process is used to understand difference of productivity in planting and cultivation and natural rubber primary processing between Cambodia and Thailand. Diffusion of agricultural technologies and diffusion of industrial technologies were separately discussed but they were not researched at the same time in the total manner. The analytic hierarchy process, developed by Satty (1980), is the method to determine and solve problems by mixing subjective judgment and system approach. This method allows to divide factors of the problem into hierarchy construction, in the relation of overall objects (level 1), evaluation standards (level 2) and alternative plan (level 3) and to seek importance from overall object to alternative plan and then to evaluate importance of alternative plan by judging each evaluation standard and finally to obtain evaluation of alternative plan from the viewpoint of overall object. In the case of the problems, of which qualitative factors are important, are analyzed, the analytic hierarchy process is used to deals with the problems such as economy, management and decision making of policy, which have been difficult to quantify and model, by incorporating sensual information as important factor. In this study, the natural rubber industry that has limitation to gather quantitative data and is greatly affected by various qualitative factors is analyzed by using this method. For selection, division and weighing of the major factors to determine productivity of planting and cultivation, and primary processing of natural rubber as well as evaluation of diffusion of technologies for productivity in Cambodia and Thailand, interviews were made with some specialists in both countries, and overall evaluation was made. In this study, analyzed by the analytic hierarchy process, "Evaluation of productivity of planting and cultivation of natural rubber and primary processing in Cambodia and Thailand" was decided as the overall object (level 1) in the first place. Next to decide evaluation standards (level 2), the nine processes as affecting factors of productivity were decided. Finally, the evaluation comparison object (level 3) was decided as Cambodia and Thailand. 


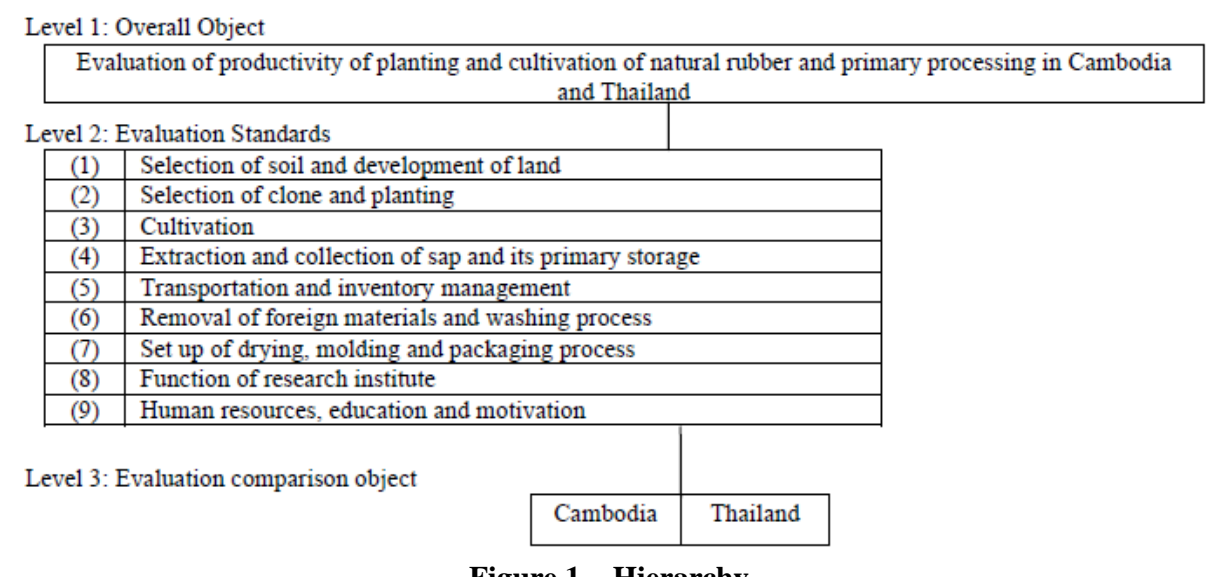

Figure 1 - Hierarchy

\section{Evaluation Results and Observation}

\subsection{Weighing evaluation standards (level 2)}

In the first place using importance scale (table 1) used in the analytical hierarchy process and based on the opinions of the above natural rubber professionals, the pair comparison for the process one to nine of evaluation standards (Level 2) was made. The pair compassion matrix is shown in the table 2 . Then, weight vector of each process by geometric average was calculated from this pair comparison matrix. Regarding processes affecting productivity of natural rubber industry, (2) Selection of clone and planting and (4) Extraction and collection of sap and its primary storage from the viewpoint of agricultural technologies and (6) removal of foreign materials and washing process from the view point of industrial technologies and also (8) function of research institute and (9) human resources, education and motivation has turned to be important.

\subsection{Weighing evaluation levels}

To analyze evaluation comparison object (level 3) by using absolute evaluation method, evaluation levels (table 4) of absolute evaluation standards and difference scale of evaluation standard (table 3), which is usually used in the hierarchy process, for each factor of evaluation level (level 2) were determined. Then, pair comparison of evaluation level based on this scale was made and pair comparison matrix was obtained (table 5). Using this matrix, each weight vector was calculated (table 6).

Table 1 - Scale of Importance

\begin{tabular}{c|c|c|c|c|c}
\hline Scale & 1 & 3 & 5 & 7 & 9 \\
\hline Definition & equally & more important & fairly important & very important & Extremely important \\
\hline
\end{tabular}


Table 2 - Pair Comparison Matrix and Weight Vector of Evaluation Standards (Level 2)

\begin{tabular}{l|l|c|c|c|c|c|c|c|c|c|c}
\hline & \multicolumn{1}{|c|}{ Factor } & $(1)$ & $(2)$ & $(3)$ & $(4)$ & $(5)$ & $(6)$ & $(7)$ & $(8)$ & (9) & $\begin{array}{c}\text { Weight } \\
\text { vector }\end{array}$ \\
\hline$(1)$ & $\begin{array}{l}\text { Selection of soil and } \\
\text { development of land }\end{array}$ & 1 & $1 / 9$ & $1 / 5$ & $1 / 7$ & $1 / 3$ & $1 / 7$ & 1 & $1 / 9$ & $1 / 7$ & 0.017 \\
\hline$(2)$ & $\begin{array}{l}\text { Selection of clone and } \\
\text { planting }\end{array}$ & 9 & 1 & 5 & 3 & 7 & 3 & 9 & 1 & 3 & 0.255 \\
\hline$(3)$ & Cultivation & 5 & $1 / 5$ & 1 & $1 / 3$ & 7 & $1 / 3$ & 7 & $1 / 5$ & $1 / 3$ & 0.065 \\
\hline$(4)$ & $\begin{array}{l}\text { Extraction and collection of } \\
\text { sap and its primary storage }\end{array}$ & 7 & $1 / 3$ & 3 & 1 & 5 & 1 & 9 & $1 / 3$ & 1 & 0.122 \\
\hline (5) & $\begin{array}{l}\text { Transportation and } \\
\text { inventory management }\end{array}$ & 3 & $1 / 7$ & $1 / 7$ & $1 / 5$ & 1 & $1 / 5$ & 1 & $1 / 7$ & $1 / 7$ & 0.024 \\
\hline (6) & $\begin{array}{l}\text { Removal of foreign } \\
\text { materials and washing } \\
\text { process }\end{array}$ & 7 & $1 / 3$ & 3 & 1 & 5 & 1 & 9 & $1 / 5$ & $1 / 3$ & 0.102 \\
\hline (7) & $\begin{array}{l}\text { Set up of drying, molding } \\
\text { and packaging process }\end{array}$ & 1 & $1 / 9$ & $1 / 7$ & $1 / 9$ & 1 & $1 / 9$ & 1 & $1 / 9$ & $1 / 7$ & 0.018 \\
\hline (8) & $\begin{array}{l}\text { Function of research } \\
\text { institute }\end{array}$ & 9 & 1 & 5 & 3 & 7 & 5 & 9 & 1 & 1 & 0.238 \\
\hline (9) & $\begin{array}{l}\text { Human resources, education } \\
\text { and motivation }\end{array}$ & 7 & $1 / 3$ & 3 & 1 & 7 & 3 & 7 & 1 & 1 & 0.158 \\
\hline
\end{tabular}

\subsection{Evaluation of comparison object}

With regard to Evaluation standards (level 2) for each process, evaluation of Cambodia and Thailand or comparison object (level 3) was made by the professionals indicated in the above. The results is shown in the table 7 based on their opinion and evaluation levels of absolute evaluation standards. Following is the observation about difference of productivity caused by diffusion level of technologies in natural rubber industry.

First of all, it became clear that there can be seen difference in the all production processes from land development by developers, planting and cultivation of natural rubber by farmers, transportation by middlemen to primary processing by manufacturers and also about function of research institutes and level of human resources between Cambodia and Thailand. The overall evaluation figures of comparison object (level 3) were calculated by using weight vector (table 8) which was obtained by dividing weight vector of each evaluation standards (table 2) and weight vector of each evaluation level with each maximum evaluation figure. Cambodia scored 0.149 and Thailand scored 0.585 (table 9).

Secondary, there can be seen difference about agricultural technologies such as clone selection, planting, extraction and collection of sap and primary storage between two countries. As to clone, in particular at the time of planting and replanting, Thailand introduced newly developed high yield specimen which brought effect. There can be also seen difference about knowledge and know-how about extraction and collection of sap and primary storage between the two countries.

Table 3 - Difference Scale of Evaluation Standards

\begin{tabular}{c|c|c|c|c|c}
\hline Scale & 1 & 3 & 5 & 7 & 9 \\
\hline Definition & Equally & small & bigger & big & extremely big \\
\hline
\end{tabular}


Table 4 - Evaluation Standards

\begin{tabular}{|c|c|c|c|c|c|}
\hline & Factor & $\mathrm{A}$ & $\mathrm{B}$ & $\mathrm{C}$ & $\mathrm{D}$ \\
\hline (1) & $\begin{array}{c}\text { Selection of soil } \\
\text { and development } \\
\text { of land }\end{array}$ & $\begin{array}{c}\text { Abilities of } \\
\text { agricultural } \\
\text { technologies } \\
\text { development are } \\
\text { stored }\end{array}$ & $\begin{array}{c}\text { Intellectual } \\
\text { technologies are } \\
\text { diffused }\end{array}$ & $\begin{array}{c}\text { Intellectual } \\
\text { technologies (skill } \\
\text { technologies) are } \\
\text { diffused }\end{array}$ & $\begin{array}{l}\text { Technologies } \\
\text { of tangible } \\
\text { production } \\
\text { methods are } \\
\text { introduced } \\
\end{array}$ \\
\hline (2) & $\begin{array}{l}\text { Selection of } \\
\text { clone and } \\
\text { planting }\end{array}$ & $\begin{array}{c}\text { Abilities of } \\
\text { agricultural } \\
\text { technologies } \\
\text { development are } \\
\text { stored }\end{array}$ & $\begin{array}{c}\text { Intellectual } \\
\text { technologies are } \\
\text { diffused }\end{array}$ & $\begin{array}{c}\text { Intellectual } \\
\text { technologies (skill } \\
\text { technologies) are } \\
\text { diffused }\end{array}$ & $\begin{array}{l}\text { Technologies } \\
\text { of tangible } \\
\text { production } \\
\text { methods are } \\
\text { introduced }\end{array}$ \\
\hline (3) & Cultivation & $\begin{array}{c}\text { Abilities of } \\
\text { agricultural } \\
\text { technologies } \\
\text { development are } \\
\text { stored } \\
\end{array}$ & $\begin{array}{c}\text { Intellectual } \\
\text { technologies are } \\
\text { diffused }\end{array}$ & $\begin{array}{c}\text { Intellectual } \\
\text { technologies (skill } \\
\text { technologies) are } \\
\text { diffused }\end{array}$ & $\begin{array}{l}\text { Technologies } \\
\text { of tangible } \\
\text { production } \\
\text { methods are } \\
\text { introduced }\end{array}$ \\
\hline (4) & $\begin{array}{c}\text { Extraction and } \\
\text { collection of sap } \\
\text { and its primary } \\
\text { storage }\end{array}$ & $\begin{array}{c}\text { Abilities of } \\
\text { agricultural } \\
\text { technologies } \\
\text { development are } \\
\text { stored } \\
\end{array}$ & $\begin{array}{c}\text { Intellectual } \\
\text { technologies are } \\
\text { diffused }\end{array}$ & $\begin{array}{c}\text { Intellectual } \\
\text { technologies (skill } \\
\text { technologies) are } \\
\text { diffused }\end{array}$ & $\begin{array}{l}\text { Technologies } \\
\text { of tangible } \\
\text { production } \\
\text { methods are } \\
\text { introduced } \\
\end{array}$ \\
\hline (5) & $\begin{array}{c}\text { Transportation } \\
\text { and inventory } \\
\text { management }\end{array}$ & $\begin{array}{l}\text { Designing and } \\
\text { planning abilities } \\
\text { are formed }\end{array}$ & $\begin{array}{c}\text { Technologies of } \\
\text { improvement and } \\
\text { tatistical } \\
\text { management are } \\
\text { stored }\end{array}$ & $\begin{array}{l}\text { Technologies of } \\
\text { operation, } \\
\text { maintenance and } \\
\text { production } \\
\text { management are } \\
\text { diffused }\end{array}$ & $\begin{array}{l}\text { Built-in type } \\
\text { technologies } \\
\text { are introduced }\end{array}$ \\
\hline (6) & $\begin{array}{c}\text { Removal of } \\
\text { foreign materials } \\
\text { and washing } \\
\text { process }\end{array}$ & $\begin{array}{l}\text { Designing and } \\
\text { planning abilities } \\
\text { are formed }\end{array}$ & $\begin{array}{c}\text { Technologies of } \\
\text { improvement and } \\
\text { statistical } \\
\text { management are } \\
\text { stored }\end{array}$ & $\begin{array}{l}\text { Technologies of } \\
\text { operation, } \\
\text { maintenance and } \\
\text { production } \\
\text { management are } \\
\text { diffused }\end{array}$ & $\begin{array}{l}\text { Built-in type } \\
\text { technologies } \\
\text { are introduced }\end{array}$ \\
\hline (7) & $\begin{array}{c}\text { Set up of drying, } \\
\text { molding and } \\
\text { packaging } \\
\text { process }\end{array}$ & $\begin{array}{l}\text { Designing and } \\
\text { planning abilities } \\
\text { are formed }\end{array}$ & $\begin{array}{c}\text { Technologies of } \\
\text { improvement and } \\
\text { statistical } \\
\text { management are } \\
\text { stored }\end{array}$ & $\begin{array}{l}\text { Technologies of } \\
\text { operation, } \\
\text { maintenance and } \\
\text { production } \\
\text { management are } \\
\text { diffused } \\
\end{array}$ & $\begin{array}{l}\text { Built-in type } \\
\text { technologies } \\
\text { are introduced }\end{array}$ \\
\hline (8) & $\begin{array}{l}\text { Function of } \\
\text { research } \\
\text { institute }\end{array}$ & $\begin{array}{c}\text { Overall research \& } \\
\text { development are } \\
\text { executed }\end{array}$ & $\begin{array}{c}\text { Activities to } \\
\text { introduce } \\
\text { agricultural and } \\
\text { industrial } \\
\text { technologies are } \\
\text { processed }\end{array}$ & $\begin{array}{l}\text { Agricultural and } \\
\text { industrial } \\
\text { technologies are } \\
\text { introduced }\end{array}$ & $\begin{array}{l}\text { Built-in type } \\
\text { technologies } \\
\text { are introduced }\end{array}$ \\
\hline
\end{tabular}


Human resources, education and motivation
Professional education are supplied, Motivation is extremely high
Highly education are supplied, Motivation is high
Basic agricultural and industrial technologies are supplied,

Motivation is average
Compulsory education are supplied Motivation is low

Table 5 - Pair Comparison Matrix of Evaluation Standards

(1) Selection of soil and development of land

\begin{tabular}{c|c|c|c|c}
\hline & $\mathrm{A}$ & $\mathrm{B}$ & $\mathrm{C}$ & $\mathrm{D}$ \\
\hline $\mathrm{A}$ & 1 & 3 & 5 & 7 \\
\hline $\mathrm{B}$ & $1 / 3$ & 1 & 3 & 5 \\
\hline $\mathrm{C}$ & $1 / 5$ & $1 / 3$ & 1 & 3 \\
\hline $\mathrm{D}$ & $1 / 7$ & $1 / 5$ & $1 / 3$ & 1 \\
\hline
\end{tabular}

(4) Extraction and collection of sap and its primary storage

\begin{tabular}{|c|c|c|c|c|}
\hline & $\mathrm{A}$ & $\mathrm{B}$ & $\mathrm{C}$ & $\mathrm{D}$ \\
\hline $\mathrm{A}$ & 1 & 3 & 5 & 9 \\
\hline $\mathrm{B}$ & $1 / 3$ & 1 & 3 & 7 \\
\hline $\mathrm{C}$ & $1 / 5$ & $1 / 3$ & 1 & 5 \\
\hline $\mathrm{D}$ & $1 / 9$ & $1 / 7$ & $1 / 5$ & 1 \\
\hline
\end{tabular}

(7) Set up of drying, molding and packaging process

\begin{tabular}{|c|c|c|c|c}
\hline & $\mathrm{A}$ & $\mathrm{B}$ & $\mathrm{C}$ & $\mathrm{D}$ \\
\hline $\mathrm{A}$ & 1 & 3 & 5 & 7 \\
\hline $\mathrm{B}$ & $1 / 3$ & 1 & 3 & 5 \\
\hline $\mathrm{C}$ & $1 / 5$ & $1 / 3$ & 1 & 3 \\
\hline $\mathrm{D}$ & $1 / 7$ & $1 / 5$ & $1 / 3$ & 1 \\
\hline
\end{tabular}

(2) Selection of clone and planting

\begin{tabular}{c|c|c|c|c}
\hline & $\mathrm{A}$ & $\mathrm{B}$ & $\mathrm{C}$ & $\mathrm{D}$ \\
\hline $\mathrm{A}$ & 1 & 5 & 7 & 9 \\
\hline $\mathrm{B}$ & $1 / 5$ & 1 & 3 & 5 \\
\hline $\mathrm{C}$ & $1 / 7$ & $1 / 3$ & 1 & 3 \\
\hline $\mathrm{D}$ & $1 / 9$ & $1 / 5$ & $1 / 3$ & 1 \\
\hline
\end{tabular}

(5) Transportation and inventory management

\begin{tabular}{c|c|c|c|c}
\hline & $\mathrm{A}$ & $\mathrm{B}$ & $\mathrm{C}$ & $\mathrm{D}$ \\
\hline $\mathrm{A}$ & 1 & 3 & 5 & 7 \\
\hline $\mathrm{B}$ & $1 / 3$ & 1 & 3 & 5 \\
\hline $\mathrm{C}$ & $1 / 5$ & $1 / 3$ & 1 & 3 \\
\hline $\mathrm{D}$ & $1 / 7$ & $1 / 5$ & $1 / 3$ & 1 \\
\hline
\end{tabular}

(8) Function of research institute

\begin{tabular}{c|c|c|c|c}
\hline & $\mathrm{A}$ & $\mathrm{B}$ & $\mathrm{C}$ & $\mathrm{D}$ \\
\hline $\mathrm{A}$ & 1 & 5 & 7 & 9 \\
\hline $\mathrm{B}$ & $1 / 5$ & 1 & 3 & 5 \\
\hline $\mathrm{C}$ & $1 / 7$ & $1 / 3$ & 1 & 3 \\
\hline $\mathrm{D}$ & $1 / 9$ & $1 / 5$ & $1 / 3$ & 1 \\
\hline
\end{tabular}

(3) Cultivation

\begin{tabular}{c|c|c|c|c}
\hline & $\mathrm{A}$ & $\mathrm{B}$ & $\mathrm{C}$ & $\mathrm{D}$ \\
\hline $\mathrm{A}$ & 1 & 3 & 5 & 7 \\
\hline $\mathrm{B}$ & $1 / 3$ & 1 & 3 & 5 \\
\hline $\mathrm{C}$ & $1 / 5$ & $1 / 3$ & 1 & 3 \\
\hline $\mathrm{D}$ & $1 / 7$ & $1 / 5$ & $1 / 3$ & 1 \\
\hline
\end{tabular}

(6) Removal of foreign materials and washing process

\begin{tabular}{c|c|c|c|c}
\hline & $\mathrm{A}$ & $\mathrm{B}$ & $\mathrm{C}$ & $\mathrm{D}$ \\
\hline $\mathrm{A}$ & 1 & 3 & 7 & 9 \\
\hline $\mathrm{B}$ & $1 / 3$ & 1 & 5 & 7 \\
\hline $\mathrm{C}$ & $1 / 7$ & $1 / 5$ & 1 & 3 \\
\hline $\mathrm{D}$ & $1 / 9$ & $1 / 7$ & $1 / 3$ & 1 \\
\hline
\end{tabular}

(9) Human resources, education and motivation

\begin{tabular}{c|c|c|c|c}
\hline & $\mathrm{A}$ & $\mathrm{B}$ & $\mathrm{C}$ & $\mathrm{D}$ \\
\hline $\mathrm{A}$ & 1 & 3 & 7 & 9 \\
\hline $\mathrm{B}$ & $1 / 3$ & 1 & 5 & 7 \\
\hline $\mathrm{C}$ & $1 / 7$ & $1 / 5$ & 1 & 3 \\
\hline $\mathrm{D}$ & $1 / 9$ & $1 / 7$ & $1 / 3$ & 1 \\
\hline
\end{tabular}

\begin{tabular}{c|c|c|c|c|c|c|c|c|c}
\hline & $(1)$ & $(2)$ & $(3)$ & $(4)$ & $(5)$ & $(6)$ & $(7)$ & $(8)$ & $(9)$ \\
\hline $\mathrm{A}$ & 0.564 & 0.654 & 0.564 & 0.565 & 0.564 & 0.582 & 0.564 & 0.654 & 0.582 \\
\hline $\mathrm{B}$ & 0.263 & 0.204 & 0.263 & 0.270 & 0.263 & 0.290 & 0.263 & 0.204 & 0.290 \\
\hline $\mathrm{C}$ & 0.118 & 0.096 & 0.118 & 0.126 & 0.118 & 0.085 & 0.118 & 0.096 & 0.085 \\
\hline $\mathrm{D}$ & 0.055 & 0.046 & 0.055 & 0.039 & 0.055 & 0.042 & 0.055 & 0.046 & 0.042 \\
\hline
\end{tabular}

Table 6 - Weight Vector of Evaluation Standards

\begin{tabular}{c|c|c|c|c|c|c|c|c|c}
\hline & $(1)$ & $(2)$ & $(3)$ & $(4)$ & $(5)$ & $(6)$ & $(7)$ & \multicolumn{1}{c}{$(8)$} & $(9)$ \\
\hline $\mathrm{A}$ & 0.564 & 0.654 & 0.564 & 0.565 & 0.564 & 0.582 & 0.564 & 0.654 & 0.582 \\
\hline $\mathrm{B}$ & 0.263 & 0.204 & 0.263 & 0.270 & 0.263 & 0.290 & 0.263 & 0.204 & 0.290 \\
\hline $\mathrm{C}$ & 0.118 & 0.096 & 0.118 & 0.126 & 0.118 & 0.085 & 0.118 & 0.096 & 0.085 \\
\hline $\mathrm{D}$ & 0.055 & 0.046 & 0.055 & 0.039 & 0.055 & 0.042 & 0.055 & 0.046 & 0.042 \\
\hline
\end{tabular}

Thirdly, there can be seen big difference about industrial technologies such as removal of foreign materials and washing process between the two countries. Insufficient level about these processes causes low quality of primary processed natural rubber products. Particularly, if natural rubbers without removing metals, plastics in the foreign material removing process 
are passed to the downstream process such as drying and molding, they become inferior products and cannot be returned to the upstream process for rework and eventually cause low productivity. As diffusion of built-in type technologies, for example, metal detector, is not sufficient in Cambodia. Cambodia remains behind Thailand in intellectual knowledge and know-how about production management and quality control.

In the fourth, as to agricultural technologies development of clone, its selection and planting technologies to suit to environment is important. Rubber Research Institutes of Thailand, public laboratory, conducts overall research and development in Thailand. On the other hand, Cambodian Rubber Research Institute has still some problems to overcome in this regard. Then, industrial technologies and knowledge and know-how accumulated by natural rubber primary processing companies contribute to productivity. Built-in type technologies are possible to bring in to the country by purchasing machineries and equipment but knowledge and know-how about production are not transferred when the two concerned countries are in the competitive situation. Therefore public research institute plays important role and there can be seen obvious difference about the role between the two countries.

In the fifth, as to human resources, education and motivation, particularly basic education is much behind Thailand due to the historical reason of the long civil war in Cambodia. There can be also seen gap of motivation between the two countries caused by consequence from the situation that most of Thai farmers are independent farmers and most of Cambodian farmers are employed by plantations.

Table 7 - Evaluation Standards (Level 3)

\begin{tabular}{c|c|c|c|c|c|c|c|c|c}
\hline & $(1)$ & $(2)$ & $(3)$ & $(4)$ & $(5)$ & $(6)$ & $(7)$ & $(8)$ & $(9)$ \\
\hline Cambodia & $\mathrm{B}$ & $\mathrm{C}$ & $\mathrm{C}$ & $\mathrm{C}$ & $\mathrm{C}$ & $\mathrm{D}$ & $\mathrm{C}$ & $\mathrm{C}$ & $\mathrm{D}$ \\
\hline Thailand & $\mathrm{A}$ & $\mathrm{B}$ & $\mathrm{B}$ & $\mathrm{B}$ & $\mathrm{A}$ & $\mathrm{B}$ & $\mathrm{B}$ & $\mathrm{A}$ & $\mathrm{B}$ \\
\hline
\end{tabular}

Table 8 - Weight Vector of Evaluation Standards Divided by Maximum Evaluation Figure

\begin{tabular}{c|c|c|c|c|c|c|c|c|c}
\hline & $(1)$ & $(2)$ & $(3)$ & $(4)$ & $(5)$ & $(6)$ & $(7)$ & $(8)$ & $(9)$ \\
\hline $\mathrm{A}$ & 1.000 & 1.000 & 1.000 & 1.000 & 1.000 & 1.000 & 1.000 & 1.000 & 1.000 \\
\hline $\mathrm{B}$ & 0.466 & 0.312 & 0.466 & 0.478 & 0.466 & 0.498 & 0.466 & 0.312 & 0.498 \\
\hline $\mathrm{C}$ & 0.209 & 0.147 & 0.209 & 0.223 & 0.209 & 0.146 & 0.209 & 0.147 & 0.146 \\
\hline $\mathrm{D}$ & 0.098 & 0.070 & 0.098 & 0.069 & 0.098 & 0.072 & 0.098 & 0.070 & 0.072 \\
\hline
\end{tabular}

Table 9 - Evaluation of Cambodia and Thailand

\begin{tabular}{c|c|c|c|c|c|c|c|c|c|c}
\hline & $(1)$ & $(2)$ & $(3)$ & $(4)$ & $(5)$ & $(6)$ & $(7)$ & $(8)$ & $(9)$ & $\begin{array}{c}\text { Overall } \\
\text { evaluatio }\end{array}$ \\
\hline Cambodia & 0.008 & 0.037 & 0.014 & 0.027 & 0.005 & 0.007 & 0.004 & 0.035 & 0.011 & 0.149 \\
\hline Thailand & 0.017 & 0.080 & 0.030 & 0.058 & 0.024 & 0.051 & 0.008 & 0.238 & 0.079 & 0.585 \\
\hline
\end{tabular}

\section{Conclusion}

In this study, using hierarchy analytical method, the productivity difference about planting and cultivation of natural rubber and its primary processing between Cambodia and Thailand was analyzed from the view point of technology diffusion. As a result, it was found that the difference between the two countries ranges from the level of diffusion of agricultural and industrial technologies, function of research institute to the level of human resources. 
Among them clone technology in terms of agricultural technologies, foreign materials removal problem in terms of industrial technologies and gap of human resources and research institutes are highlighted. As there is limitation to develop resources, such as human resources, materials and information in the developing countries, it is important to prioritize introduction of technologies, strengthening of research function and development of human resources.

\section{References}

[1] Everett, E. Rogers. Diffusion of Innovations, Fifth Edition[M]. New York: Free Press, 2003

[2] International Rubber Study Group[J]. Rubber Statistical Bulletin, 2008, 62(6/7)

[3] Thomas, L. Satty. The Analytic Hierarchy Process[M]. New York: McGraw-Hill Inc, 1980 